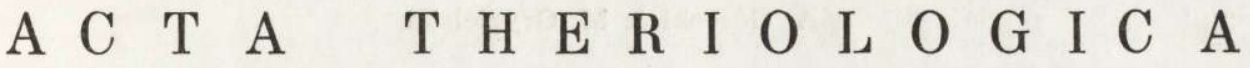

VOL. 20, 18: 237-246.

June, 1975

Andrzej GÓRECKI \& Małgorzata GRYGIELSKA

\section{Consumption and Utilization of Natural Foods by the Common Hamster *}

[With 6 Tables \& 1 Fig.]

The food preference of hamsters, Cricetus cricetus (L in na eus, 1758), was investigated in summer and autumn by the method of stomach analysis. In summer green parts of wheat, rape and clover, as well as seeds of poppy and invertebrates, dominate in the food of hamsters. In autumn hamsters eat mainly clover, potatoe tubers, invertebrates and wheat corn. Moreover, consumption and utilization of concentrated foods (seeds of oat, wheat, corn, and Vicia faba minor), and bulky foods (green wheat, beetroot, alfalfa) was determined. The digessted energy ranged from 56 to $91 \%$, and metabolizable energy from 50 to $79 \%$, and was higher for concentrated foods. On the basis of the obtained results an attempt was made to estimate the effect of hamsters on plantations.

\section{INTRODUCTION}

In order to determine the energy flow on the basis of feeding experiments it is essential to know the quality and quantity of consumed food, as well as the amount of energy assimilated by the animal and that dissipated from the organism to the ecosystem. This study was aimed at the determination of food preference of hamsters Cricetus cricetus ( $\mathrm{L}$ i n$\mathrm{n}$ a e u s, 1758), and also estimation of consumption and utilization of natural foods by these animals.

Hamster is a hibernating and for this reason the period of its winter sleep has been mainly studied hitherto ( $\mathrm{K}$ a y s e $\mathrm{r}$, 1971); moreover, some authors investigated the biology and ecology of this species ( $\mathrm{K} \mathrm{a}$ raseva \& Shilayeva, 1965; Erdakov, 1972; Mohr et al., 1973). Hamster is one of the bigger rodents occurring in Poland; its range includes central and southern part of the country. As the predominantly herbivorous animal accumulating winter food reserves it can cause losses in the field crops.

* Praca została wykonana w ramach problemu węzłowego $\mathrm{Nr}$ 09.1.7 koordynowanego przez Instytut Ekologii PAN. 


\section{MATERIAL AND METHODS}

The studies on the diet composition by analysis of stomach content and on the consumption and food utilization were carried out on hamsters trapped in the Vistula valley some $80 \mathrm{~km}$ east of Krakow.

The analysis of stomach contents was carried out microscopically following the method of Williams $(1955,1962)$, Holišova $(1959,1965)$ and Drożd ż (1966). From each stomach usually 6 preparations were made, and additionally some control preparations were obtained from the most commonly cultivated plants in order to identify fragments of epiderm and starch in hamster stomach. The slides were analyzed under magnification $500 \times$.

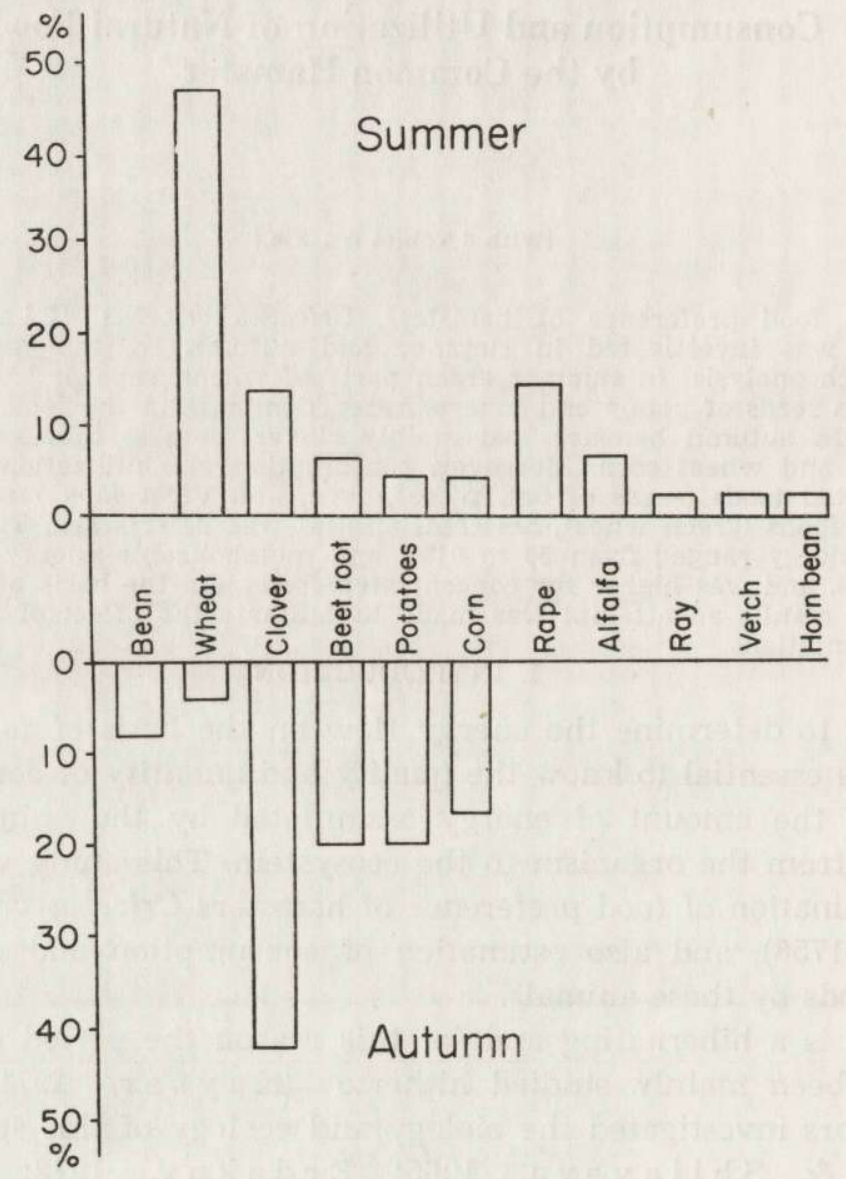

Fig. 1. Percentage distribution of hamsters trapped in different plantations.

For the studies of food composition 100 stomachs were used, including 75 organs from the animals trapped in summer 1972 (June, July) and 25 organs from the animals trapped in autumn 1972 (October, November) in various plantations (Fig. 1).

Consumption, digestibility and assimilation of 7 natural foods were investigated in the total number of $\mathbf{3 5}$ animals. In each experiment 4 to 7 animals were used. 
The investigations were carried out using both bulky foods (beetroot, alfalfa, green wheat) and concentrated foods (oat, wheat, corn and Vicia faba minor). Hamsters employed in the experiments were kept singly in metabolic cages (D r o ż d ż, 1968).

Five-day experiments were carried out at ambient temperature of $20^{\circ} \mathrm{C} \pm 2^{\circ} \mathrm{C}$ and at 12-hour light rhythm. Quantitatively collected feaces and non-consumed food were dried in an oven at $60^{\circ} \mathrm{C}$ while urine acidified with $1 \% \mathrm{H}_{2} \mathrm{SO}_{4}$ was stored in a refrigerator at $+4^{\circ}$ (D r o ż d $\dot{z}, 1968$ ).

The caloric value of food and feaces was determined in a calorimetric bomb (Górecki, 1965), while the caloric value of urine was determined with the method of $\mathrm{Nijkamp} \mathrm{(1965).} \mathrm{The} \mathrm{obtained} \mathrm{figures} \mathrm{were} \mathrm{evaluated} \mathrm{by} \mathrm{Student's}$ $t$-test.

\section{RESULTS}

\section{Analysis of Stomach Contents}

Macroscopic analysis of stomach contents showed the existence of such elements as roots, parts of stems, seeds, invertebrate animals and muscles of vertebrates. Altogether macroscopic parts of plants and animals were found in 53 cases out of 100 analyzed stomachs. The seeds of poppy and invertebrates occurred most often - in $41.5 \%$ of stomachs.

The presence of starch in the analyzed stomachs is strictly correlated with the type of actually cultivated plants. In summer the most fre-

\section{Table 1}

Foods identified in hamster stomachs by the analysis of starch granules in summer. Values indicate percentage.

\begin{tabular}{lrrr}
\hline Foods & Summer & Autumn & $\begin{array}{c}\text { Annual } \\
\text { mean }\end{array}$ \\
\hline Seeds & & & \\
Wheat & 75.5 & 16.7 & 60.6 \\
Potatoes & 3.8 & 44.4 & 14.1 \\
Corn & 13.1 & 22.2 & 15.5 \\
Oats & 3.8 & 5.6 & 4.2 \\
Alfalfa & 3.8 & - & 2.8 \\
Beans & - & 11.1 & 2.8 \\
\hline
\end{tabular}

Table 2

\begin{tabular}{|c|c|c|c|}
\hline Foods & Summer & Autumn & $\underset{\text { mean }}{\text { Annual }}$ \\
\hline Wheat & 31.6 & 15.0 & 27.5 \\
\hline Clover & 16.0 & 25.0 & 18.1 \\
\hline Rape & 16.1 & - & 13.4 \\
\hline Beet & 11.5 & 12.5 & 11.7 \\
\hline Potatoes & 3.9 & 22.5 & 8.2 \\
\hline Corn & 6.1 & 12.5 & 7.6 \\
\hline Alfalfa & 9.2 & - & 7.6 \\
\hline Oats & - & - & 2.9 \\
\hline Beans & - & 5.0 & - \\
\hline Others & 5.6 & 7.5 & 3.0 \\
\hline
\end{tabular}

quently was found wheat starch $(75.5 \%$ of stomachs) followed by corn starch. Also some starch from potatoes, oat and alfalfa seeds were detected (Table 1). On the other hand, in autumn dominated potatoe starch $(44.4 \%)$ and corn starch, while starch from wheat, beans and alfalfa was less abundant (Table 1). After summarizing the above data it appears that wheat starch dominated in the diet of hamster during the whole vegetation period as found in $60.6 \%$ of stomachs, while starch of corn 
and potatoe occurred in approximately $14.5 \%$ of stomachs on the average (Table 1).

The results of microscopic analyses indicate that hamsters consume green parts of almost all cultivated plants. However, the type of food is strictly correlated with the season (Table 2). In summer epidermis of wheat was found most often in the stomachs of hamsters $(31.6 \%)$, followed by rape and clover $(16 \%$ each). Further place were occupied by beetroot, alfalfa, corn and potatoe. The epidermis of oat, Vicia faba minor and rye were found only occasionally. In autumn dominated clover and potatoes ( $24 \%$ on the average) followed by green parts of wheat, beetroot and corn (Table 2). Employing the analysis of epidermis 11 plant species commonly occurring in cultivated fields and consumed by ham-

Table 3

Foods consumed by hamsters (in percent).

\begin{tabular}{lrrr}
\hline Foods & Summer & Autumn & $\begin{array}{c}\text { Annual } \\
\text { mean }\end{array}$ \\
\hline Seeds & & & \\
Wheat & 17.7 & 5.0 & 15.2 \\
Poppy & 9.7 & - & 7.8 \\
Corn & 3.1 & 6.7 & 3.6 \\
Greens & & & \\
Wheat & 18.1 & 10.0 & 16.5 \\
Clover & 9.3 & 16.8 & 10.9 \\
Rape & 9.7 & - & 8.0 \\
Beet & 6.6 & 8.3 & 7.0 \\
Potatoes & $-\overline{15}$ & 15.0 & 5.2 \\
Corn & 3.5 & 8.3 & 4.5 \\
Alfalfa & 5.3 & - & 4.5 \\
Invertebrates & 6.2 & 13.4 & 7.7 \\
Vertebrates & $-\overline{3.3}$ & 3.3 & 1.2 \\
Others & 10.8 & 10.2 & 7.9 \\
\hline
\end{tabular}

sters were identified. Wheat and clover, as well as rape and beetroot dominated during all the year (Table 2).

Estimating the composition of hamster's food by all the employed methods clearly indicates significant differences between summer and autumn. In summer green parts of wheat dominate $(18.1 \%)$ and are followed by wheat grain $(17.7 \%$ ), as well as by green parts of rape and clover, and seeds of poppy. The food in this period also includes beetroot, invertebrates and green alfalfa. In autumn clover is the most often consumed food ( $16.8 \%$ of stomachs) followed by potatoes, invertebrate animals and green wheat (Table 3).

The summarized data on the food constituents cosumed by hamsters during the whole year indicate that the diet is dominated by green wheat and its grain found in $16.5 \%$ of stomachs. Further places are oc- 
cupied by clover, rape, poppy seeds, invertebrates and beetroots (found in seven to ten per cent of stomachs). Seeds of grass, rape and oat were observed in very few cases only (1 to $1.7 \%$ of stomachs) while the presence of green parts of rye, bean and seeds of alfalfa and bean, as well as muscles of vertebrate animals was below $1 \%$ (Table 3 others).

\section{Consumption and Utilization of Foods}

Studies on the consumption, digestibility and assimilation were carried out on natural bulky and concentrated foods. Hence the examined food showed considerable differences in the content of water and in caloric values. These values ranged from $3.519 \mathrm{kcal} / \mathrm{g}$ dry weight for corn to $4.510 \mathrm{kcal} / \mathrm{g}$ dry weight for alfalfa (Table 4). Daily food requirement depended on the type of food, its caloric value and body weight of the animal (Table 4).

The animals fed with bulky food consumed the highest amount of alfalfa - $61.42 \mathrm{kcal} /$ day, and the lowest energy intake was observed during consumption of green wheat $-15.17 \mathrm{kcal}$. Among concentrated foods the animals consumed the highest amount of wheat and the lowest amount of corn (Table 4).

Statistically highly significant differences occurred between green wheat and corn in comparison with all the remaining foods $(P<0.001)$.

Losses of energy with feaces and urine expressed as per cent of consumed energy amount to $1.3-5.6 \%$ for urine, while for feaces the corresponding values are much higher and range from 8.5 to $44 \%$, depending on the diet. Among bulky foods the losses of energy with feaces show a considerable dispersal from ca $15 \%$ for beetroot to approximately $44 \%$ for alfalfa (Table 5). The energy losses with urine show much smaller differences and range from $4.6 \%$ for beetroot to $5.6 \%$ for alfalfa (Table 6). Lower values of energy losses were obtained when feeding the animals with concentrated foods. The combined mean values of energy losses with feaces and urine amount to $34.5 \%$ for bulky foods and $12.9 \%$ for concentrated foods. The coefficients of digestibility of bulky foods differ considerably: from $85.1 \%$ (beetroot) to $55.9 \%$ (alfalfa). Smaller differences in the values of digestible energy are evident in case of concentrated foods. The grain of oats shows the highest digestible energy $(91.3 \%$ ), while slightly lower values were found for Vicia faba minor and wheat. The lowest digestibility was found for corn $\left(80.3^{0} \%\right)$. Despite these differences the coefficients of digestibility of concentrated foods are higher than those of bulky foods (Table 5).

The values of assimilation were estimated only for four selected foods (Table 6). In animals fed with concentrated foods the assimilation is high- 


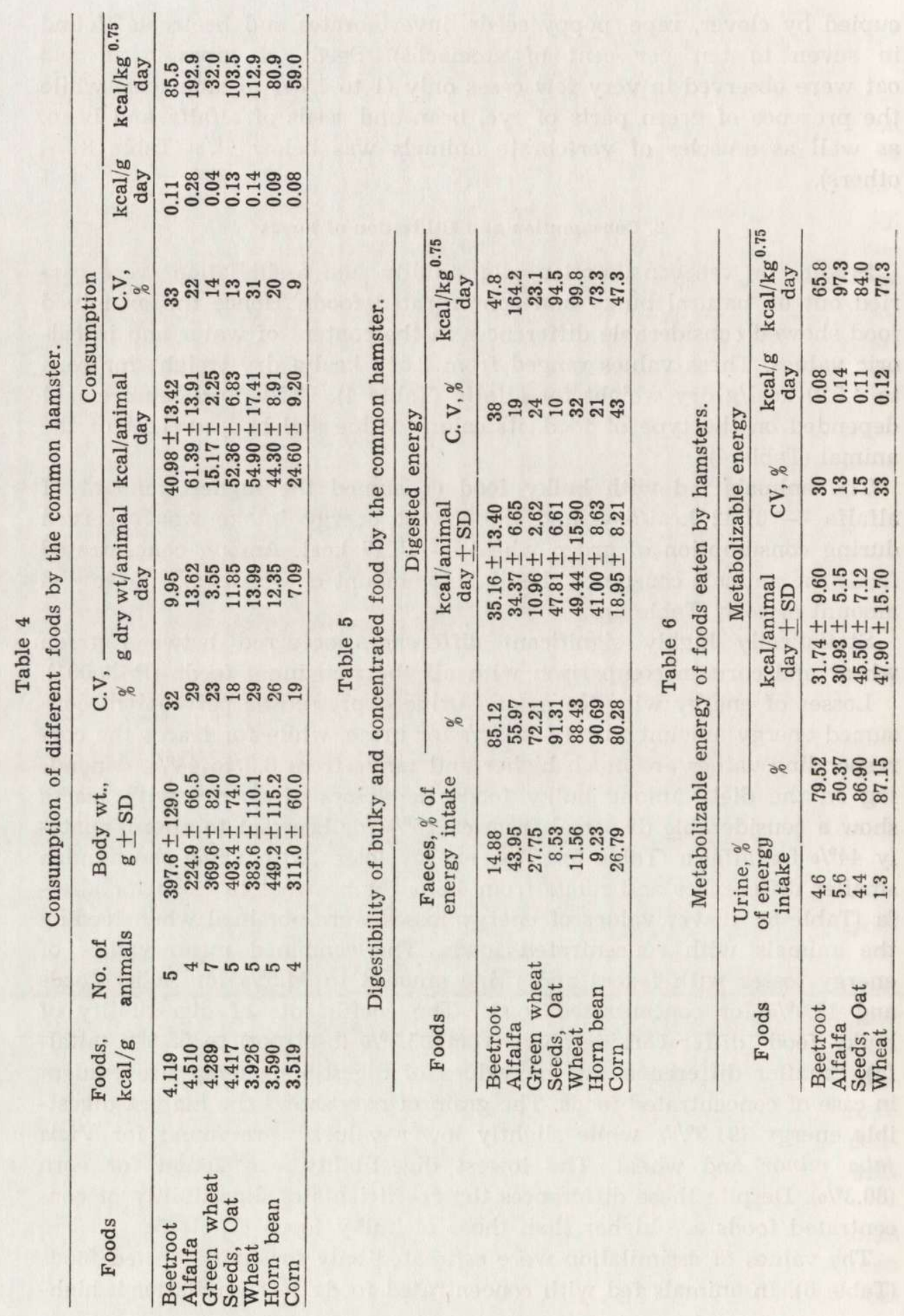


er than in those supplied with bulky foods and for wheat and oats it amounts to $87 \%$, i.e. to $47 \mathrm{kcal} / \mathrm{animal}$ day on the average; for beetroot assimilation is ca $79 \%(32 \mathrm{kcal})$ and for alfalfa $50 \%$ (39 kcal). Statistically significant differences occur between alfalfa and wheat, between oat and wheat and beetroot, as well as between oat and alfalfa $(P<0.002)$.

\section{DISCUSSION}

\section{Consumption and Utilization of Foods}

In relation to very variegated food utilized by free living hamsters the most commonly cultivated plants were employed in the feeding experiments as both bulky and concentrated foods ( $\mathrm{S} \mathrm{u} \mathrm{r} \mathrm{dacki,} \mathrm{1964,}$ and these data). The type of food had no relation to the actual season. Despite this fact the hamsters well adapted themselves to the consumption of different foods in agreement with their considerable alimentary plasticity. In this respect hamster can be compared only with the bank vole (Clethrionomys glareolus) which during the year consumes equally willingly concentrated food under the form of seeds of trees and shrubs, and bulky foods under the form of herb layer plants (D r o $\dot{z} \mathrm{~d} \dot{z}, 1966$ ).

E r d a k ov (1972) carrying feeding experiments on young hamsters (body weight $185.3 \mathrm{~g}$ ) obtained higher values of consumption than those found in the present study (Table 4): they amounted to $79.4 \mathrm{kcal} / \mathrm{animal}$ day. On account of intensive growth the energy requirements of younger animals are higher than of adults, and this fact sufficiently explains the differences in the values obtained by $\mathrm{Erdakov}$ and by us.

Bulky foods are characterized by a low coefficient of digestibility which in hamsters ranged from ca $56 \%$ for alfalfa to ca $85 \%$ for beetroot. Bulky foods contain considerable amounts of fiber, which decreases the efficiency of digestion ( $\mathrm{Nehring}$, 1959; Nehring et al., 1965; Davis \& Golley, 1963). The low coefficient of digestibility of bulky foods is also related to a high content of water decreasing the caloric value of the consumed biomass.

In case of concentrated foods the digestible energy was found to be much higher and ranged between $80 \%$ for corn and $91 \%$ for oats. The low value of digestible energy of alfalfa $-55.9 \%$ is similar to that found for grass - 55.2\% in Arvicola terrestris (D r o ż d $\dot{z}$ et al., 1971). Similarly the value of green wheat amounts to $72.2 \%$ in hamster and $70.4 \%$ in Microtus arvalis (D ro $\dot{z} d \dot{z}, 1968$ ). The values of digestible energy for oat are most close for hamster and other rodents: hamster $91.3 \%$, common vole $92.3 \%$, bank vole $89.1 \%$, field mouse $90.4 \%$ (D r o ż d $\dot{z}$, 1968). Lower utilization of bulky foods by hamsters is also indicated by the value of energy losses with feaces and urine, which amount on the average to $34.5 \%$. On the other hand, corresponding losses for concen- 
trated foods amount to $13 \%$ only. The mean assimilation value of examined bulky foods amounts to $65.4 \%$ and is only slightly different from the value of assimilation of green wheat in common vole $-65.2 \%$ (D r o ż d $\dot{z}, 1968$ ), and from the mean assimilation value for Arvicola terrestris (D ro $\dot{z} \mathrm{~d} \dot{z}$, et al., 1971). Assimilation of bulky foods in hamsters amounts to $87 \%$, while in common vole, bank vole and field mouse it ranges from 86 to $89.7 \%$ (D r o ż d $\dot{z}, 1968$ ). The hamsters assimilated on the average approximately $39 \mathrm{kcal} / \mathrm{animal}$ day, hence the utilization of foods was considerably lower than in the experiments carried out by E r d a k ov (1972), in which the amount of metabolizable energy amounted to ca $63 \mathrm{kcal} / \mathrm{animal}$ day. This can be explained by employment in these experiments young, intensively growing animals.

\section{The Effect of Hamsters on Plantations}

In the Vistula valley, where the population of hamsters was investigated in spring and summer 1972 their density was 6 animals/ha. In autumn 1972 the number of hamsters doubled to the value of 13 animals/ /ha (G ó recki, unpubl. data). At this density they can inflict some damages to agrocenoses. On the basis of the data obtained in the present study on the food preference, consumption and energy requirements the losses caused by hamsters were estimated. Such an attempt is of course not accurate as it based on incomplete data but in gives an approximation of losses caused in natural conditions by these rodents.

In the period of activity, corresponding to spring and summer, i.e. during 6 months one hamster consumes mainly green parts of plants taking up in this period jointly ca $11,000 \mathrm{kcal}$. When assuming the presence of only 6 hamsters/ha it was calculated that they consume 9 million kcal, i.e barely $0.05 \%$ losses in the total biomass of cultivated fields.

In autumn the losses caused by hamsters are much higher due to storing grain. According to various authors food reserves accumulated by these rodents range from a dozen or so to a few dozens of kilograms. Feriancova-Masarova \& Hanák (1965) reported that the reserves of a hamster are around $15 \mathrm{~kg}$, while according to W a l ke r (1964) they may amount to $90 \mathrm{~kg}$ of grain. Taking into account the fact that the latter figure corresponds probably to maximum values it was assumed that the mean food reserve of a hamster is $20 \mathrm{~kg}$. In the examined area the plantations of corn include 70 ha and yield ca $2000 \mathrm{q}$ of corn, out of which as much as $180 \mathrm{q}$ or $9 \%$ can be accumulated by hamsters in underground burrows. Hence during the whole year these rodents cause considerable losses in the total production of plantations, especially in respect of grain.

An additional effect of hamsters on the environment depends on the 
fact that their excrements remain in the ecosystem and are utilized for the new primary production. One hamster excretes daily ca $1.2 \mathrm{~g}$ of dry weight of feaces, or $438 \mathrm{~g}$ per year. This is a higher value than the body weight of a single hamster $(362 \mathrm{~g})$. However, most of the feaces are deposited in special burrows at the depth of $1-1.5 \mathrm{~m}$ ( $\mathrm{K}$ a r a s e$\mathrm{v}$ a \& Shil a ye va, 1965) and hence their decomposition is slow and return to the ecosystem delayed.

\section{REFERENCES}

1. Davis D. E. \& Golley F. D., 1963: Principles in mammalogy. Reinhold Publ. Corp.: 1-335, New York.

2. Drużdż A., 1966: Food habits and food supply of rodents in the beech forest. Acta theriol., 11, 15: 363-384.

3. Drodzd $\dot{z}$ A., 1968: Digestibility and assimilation of natural foods in small rodents. Acta theriol., 13, 21: 367-389.

4. Drożḋ A., Górecki A., Grodziński \& Pelikan J., 1971: Bioenergetics of water voles (Arvicola terrestris L.) from southern Moravia. Ann. Zool. Fennici 8: 97-103.

5. Erdakov L. N., 1972: Potrieblienie energi i koeficent utylizaci u obyknoviennovo homjaka i vodjanoj krysy. Ekologija, 1: 66-69.

6. Feriancova-Masarova E. \& Hanák V., 1965: Cicavce. Wyd. Slov. Akad. Vied: 1-332, Bratislava.

7. Górecki A., 1965: Kalorymetr w badaniach ekologicznych. Ekol. pol., B, 11: $14 \mathrm{~b}-158$.

8. Holišova V., 1959: Potrava hraboše polniho. [In: „Hraboš polni - Microtus arvalis« ed. J. Kratochvil]. Ceskoslov. Akad. Ved: 100-120, Praha.

9. Holišova V., 1965: The food of Pitymys subterraneus and P. tatricus (Rodentia, Microtidae) in the mountain zone of the Sorbeto-Piceetum. Folia zool., 14, 1: 15-28, Brno.

10. Karaseva E. B. \& Shila yeva L. M., 1965: Stroenie nor obyknovennogo homjaka v zavisimosti ot ego vozrasta i sezona goda. Bjul. mosk. Obšč. Isp. Prir., Biol., 70, 6: 30-39.

11. Kayser Ch., 1971: La depense d'energie des hibernants au cours du cycle circoannien. Comptes rendus, Biol., 165, 5: 1145-1147.

12. Kleiber M., 1961: The fire of life - an introduction to animal energetics. J. Wiley: 1-454. New York.

13. Mohr U., Schuller M., Reznik C., Aithoff J. \& Page H., 1973: Breeding of European hamsters. Lab. Animal Sci., 23, 6: 799-802.

14. Nehring K., 1959: Ogólne żywienie zwierząt. Państw. Wyd. Roln. i Leśne: 1-574. Warszawa.

15. Nehring K., Schiemann R., Hoffmann L., Klippel W. \& $\mathrm{Jentsch}$ W., 1965: Utilization of the energy concentrates in relation to their nutrient composition. [In: "Energy metabolism«, Ed. K. L. Blaxter]. Academic Press: 243-268. London - New York.

16. Nijkamp H. J., 1965: Some remarks about determination of the heat of combustion and the carbon content of urine. [In: "Energy metabolism", Ed. K. L. Blaxter]. Academic Press, 147-158. London - New York.

17. Surdacki S., 1964: Uber die Nahrung des Hamsters, Cricetus cricetus Linn a e us, 1758. Acta theriol., 9, 20: $384-386$. 
18. W a lker E. P., 1964: Mammals of the world. Hopkins Press: $647-1500$, Baltimore.

19. Williams O., 1955: The food of mice and shrews in a Colorado montane forest. Univ. Colorado Stud., Biol., 3: 109-114.

20. Williams O., 1962: A technique for studying microtine food habits. J. Mammal., 43: 365-368.

Accepted, November 27, 1974.

Department of Animal Ecology,

Jagiellonian University,

30-060 Kraków, Krupnicza 50, Poland.

Andrzej GORECKI \& Małgorzata GRYGIELSKA

\section{KONSUMPCJA I WYKORZYSTANIE NATURALNYCH POKARMOW PRZEZ CHOMIKI}

\section{Streszczenie}

Zbadano stosunki pokarmowe chomików Cricetus cricetus (Linna eus, 1758) metodą analizy żołądków. Na podstawie morfologii epiderm oznaczono zielone części 11 gatunków roślin, a na podstawie ziaren skrobi oznaczono nasiona 6 roślin uprawnych. Do badań nad składem pokarmowym użyto 100 żołądków, z których 75 zawierało pokarm z lata, a pozostałe 25 zawierało pokarm z jesieni. Zaobserwowano ścisły związek zawartości żołądków z porą roku. Analiza makroskopowa wykazała występowanie w żołądkach chomików zwierząt bezkręgowych i kręgowych. Latem w pokarmie chomików dominują zielone części pszenicy i rzepaku, ziarna maku i koniczyna. W mniejszej ilości występują zwierzęta bezkręgowe, burak pastewny i lucerna (Tabele 1, 2). Jesienią chomiki żywią się głównie koniczyną, bulwami ziemnika, bezkręgowcami, nasionami pszenicy, a także w mniejszej ilości nasionami owsa, fasoli, bobiku i zwierzętami kręgowymi. Analiza pokarmowa wykazała polifagiczność chomików, które mogą się żywić zarówno pokarmowymi objętościowymi jak i treściowymi (Tabela 3).

Przeprowadzając doświadczenia żywieniowe zbadano konsumpcję strawność i asymilację 7 naturalnych pasz u $\mathbf{3 5}$ chomików. Kaloryczność pasz treściwych użytych w đoświadczeniach wynosiła średnio $3,863 \mathrm{kcal} / \mathrm{g}$, a objętościowych $4,306 \mathrm{kcal} / \mathrm{g}$. Zwierzęta pobierały dziennie od 0,04 do $0,28 \mathrm{kcal} / \mathrm{g}$, średnio $0,12 \mathrm{kcal} / \mathrm{g}$, tj. około $52 \mathrm{kcal} /$ /zwierzę (Tabela 4). Energia strawna pasz objętościowych (pszenica zielona, burak pastewny, lucerna) wahała się od 56 do $85 \%$, a dla pasz treściwych (owies, pszenica, bobik, kukurydza) przyjmowała wartość od 80 do $91 \%$ (Tabela 5). Zwierzęta karmione paszami objętościowymi traciły z kałem i moczem $34,5 \%$ pobranej energii. W przypadku pasz treściwych energetyczne straty z kałem i moczem dochodziły do $13 \%$. Energia przemienna wyrażona w procentach wahała się od 50,5 do $79,5 \%$ dla pasz objętościowych (lucerny i buraka pastewnego), a dla pasz treściwych (owsa i pszenicy) wynosila około $87 \%$ (Tabela 6).

$\mathrm{Na}$ podstawie uzyskanych danych o wybiórczości, konsumpcji i zapotrzebowaniu energetycznym chomików podjęto próby oszacowania strat czynionych przez te gryzonie na polach uprawnych. Przy średnim zagęszczeniu 10 chomików na ha mogą one zużyč aż do $9 \%$ ogólnej produkcji pól, z czego znaczna większość strat spowodowanych jest magazynowaniem przez chomiki zapasów pokarmowych, głównie w postaci ziarn zbóż. 